\title{
Production of the Copepod Eurytemora affinis in the Bristol Channel
}

\author{
P. H. Burkill and T. F. Kendall \\ Natural Environment Research Council, Institute for Marine Environmental Research, Prospect Place, Plymouth \\ PL1 3DH, United Kingdom
}

\begin{abstract}
A shipboard method for determining development rates of copepods under prevailing conditions of food and temperature in situ is described. Abundance and development rates of Eurytemora affinis were determined at a site towards the seaward edge of its range in the Bristol Channel during 3 seasons of the year. Production of $E$. affinis varied between 0.05 and $0.61 \mu \mathrm{g} d r y$ weight $\mathrm{m}^{-3} \mathrm{~d}^{-1}$ in January and May when the numbers of this copepod were, respectively, 1.42 and $4.83 \mathrm{~m}^{-3}$. Population $\mathrm{P} / \mathrm{B}$ quotients varied between 0.03 and $0.13 \mathrm{~d}^{-1}$ giving an annual $\mathrm{P} / \mathrm{B}$ of $33 \mathrm{yr}^{-1}$. For the later developmental stages, the proportion of animals moulting daily varied between $4 \%$ and $33 \%$, depending on stage and season. The results are discussed in relation to the factors influencing population production at this site in the estuary; it is suggested that food and predation pressures may influence production more than salinity or estuarine flushing. When compared with published rates for this species fed ad-libitum on algae in the laboratory, development rates of $E$. affinis in the field were only $10 \%-82 \%$, suggesting that extrapolation of laboratory results to the field to estimated production should only be carried out with care.
\end{abstract}

\section{INTRODUCTION}

During the past half century, many efforts were made to estimate marine productivity (Harvey, 1955; Butler et al., 1979). Such studies have been carried out successfully on phytoplankton (Koblenz-Mishke et al., 1970), macrobenthos (Warwick and Price, 1975), and fish (Gulland, 1971) but far less success has been achieved for zooplankton (Tranter, 1976). Successful studies of phytoplankton production can be attributed to the convenience and precision of the ${ }^{14} \mathrm{C}$ technique (Steeman-Nielsen, 1952). In macrobenthos and fish the comparatively slow turn-over rates allow cohorts to be distinguished and their growth and mortality followed. In contrast, the general ephemerality of most zooplankton, such as copepods, in temperate latitudes results in populations that turn-over many times annually. Together with the effects of water movement, this results in continual mixing which renders the ready identification and sampling of cohorts impossible.

In an attempt to overcome these problems, studies by others have been carried out to determine the growth rates of different species of copepods under controlled conditions using algal food in the laboratory. Many of these laboratory investigations were carried out using unnaturally high algal concentrations, often more than one order of magnitude higher than those which might be expected in the open sea (Harris and Paffenhöfer, 1976a). More recently, copepod growth studies have taken into account the low particulate concentrations that are typical of the open sea; among the species studied have been Calanus helgolandicus (Paffenhöfer, 1970), Pseudocalanus elongatus (Paffenhöfer and Harris, 1976) and Temora longicornis (Harris and Paffenhöfer, 1976b). However, our observations made on the gut contents of copepods from the eastern Bristol Channel have shown that fine particulate material such as silt constitutes their predominant dietary component. The eastern Bristol Channel is a highly turbid estuary with particulate concentrations that are tidally resuspended and may exceed $800 \mathrm{ppm}$ in the study area (Joint and Pomroy, in press). This non-algal material is a major component of the natural particulate regime found in the estuarine environment and yet few studies on copepod growth have taken this important factor into account.

There have been many records of correlations between the abundance of Eurytemora affinis and abiotic environmental variables such as salinity and temperature (e.g. Jeffries, 1962; Collins and Williams, unpubl.). More recently, studies of grazing have been carried out by Allan et al. (1977) and by Richman et al. 
(1977). However, apart from the work of Heinle und Flemer (1975), little is known about the production of this species, although McLaren and Corkett (1981) have recently investigated production of $E$. herdmani. In this paper, we describe a technique for determining copepod development rates, based on simple incubation chambers, designed for use on shipboard, which allow the animals to feed on naturally occurring particulate material. We report the seasonal rates of development and production of $E$. affinis using this technique, and discuss what environmental factors may be influencing the production of $E$. affinis in the

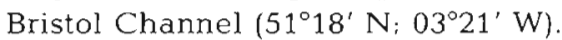

\section{MATERIALS AND METHODS}

\section{Chamber Design and Testing}

The criteria for the chamber design were as follows:

(a) The chamber should be suitable for retaining a single copepod without undue restraint, thereby allowing the development of an individual to be followed. It should also allow the free passage of seawater, so that the copepod can grow under the local ambient food and temperature conditions.

(b) The size of the chamber should be suitable for placing under a stereomicroscope for rapid observation of the copepod's developmental stage.

(c) The chamber should be sufficiently robust for use on board ship.

Incubation chambers were made from disposable polystyrene containers $(7.1 \mathrm{~cm}$ high by $5.0 \mathrm{~cm}$ diameter with a nominal capacity of $120 \mathrm{~cm}^{3}$ ). To allow seawater to pass through the chamber, holes $(2.2 \mathrm{~cm}$ diameter were drilled through opposite sides approximately 1.5 $\mathrm{cm}$ from the base and a further hole $(0.3 \mathrm{~cm}$ diameter) was drilled through the centre of the lid. The holes were covered with nylon mesh of $56 \mu \mathrm{m}$ aperture, chosen to retain all developmental stages of this species, including the nauplii which averaged $70 \mu \mathrm{m}$ at their maximum breadth (Katona, 1971).

A submersible pump (Flygt model 2040.250), mounted on the ship's hull at a depth of one metre supplied sub-surface seawater continuously to trays designed to hold the incubation chambers. Hinged lids allowed the copepods to be held in darkness, and the chambers to be readily removed for observation. The flow of seawater was regulated at a manifold to pass through the trays at an average rate of $31 \mathrm{~min}^{-1}$. This rate of flow ensured that the water in the trays remained at seawater temperature even in bright sunlight.

The following tests were carried out to check that the incubation chambers met the design requirements.
(1) Food availability: Analysis of the size distribution of particulate matter in seawater was carried out on all cruises using a Coulter Counter, (Model ZB) with $140 \mu \mathrm{m}$ and $280 \mu \mathrm{m}$ orifice tubes (Sheldon and Parsons, 1967). The size spectrum did not alter seasonally and consistently showed that the largest particles present were approximately $40 \mu \mathrm{m}$ in diameter (Fig. 1a). To check whether Eurytemora affinis consumed the larger particles which might pass more slowly through the chamber, the gut content of several freshly caught copepods was examined. The fore-gut of these animals was carefully dissected out, the contents separated by sonification (Wotton, 1977) and the particles analysed by Coulter Counter. The results (Fig. 1b, c, d) revealed that the older developmental stages of $E$. affinis were feeding on particles to a maximum size of $45 \mu \mathrm{m}$. Heinle and Flemer (1975) have reported that this species can graze on particles within the size range of 2 to $60 \mu \mathrm{m}$. These results suggested that the 56 $\mu \mathrm{m}$ mesh was unlikely to influence the quality of the food available for $E$. affinis held in the incubation chamber

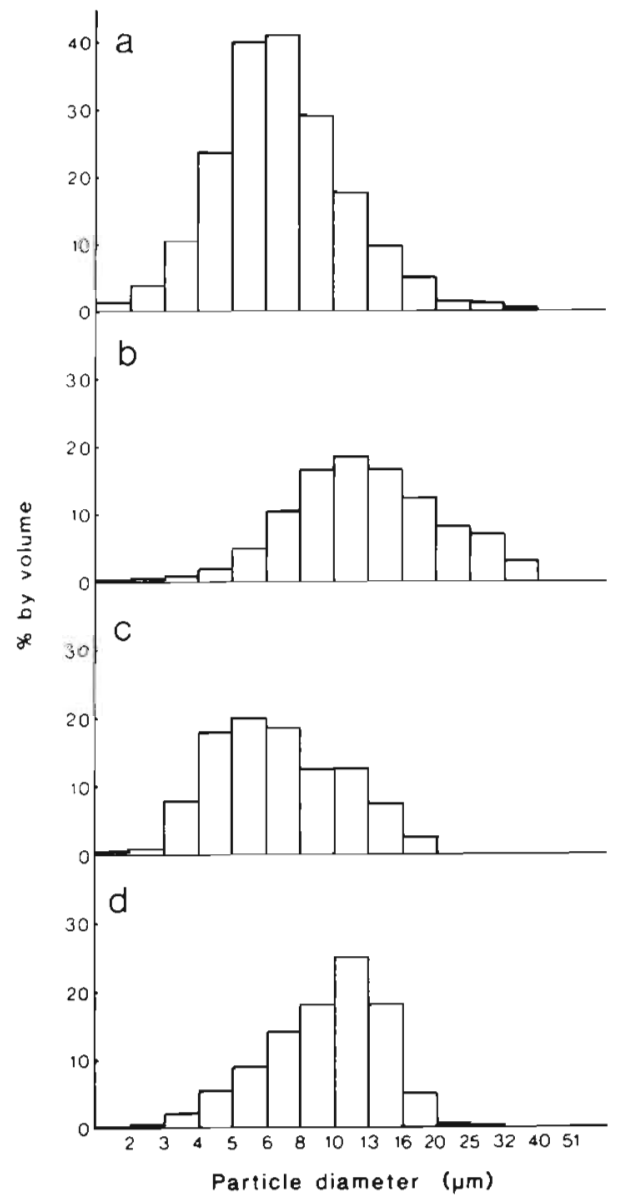

Fig. 1. Size spectrum of natural particulate material found in the water (a), and in the fore-guts of adult female copepods (b), adult male copepods (c), and copepodite Stages IV and V (d) 
It was important also to consider the quantitative supply of particulates. The maximum filtering rate of Eurytemora affinis grazing on estuarine particulates has been determined by Allan et al. (1977) to be 0.3 $\mathrm{cm}^{3}$ copepod ${ }^{-1} \mathrm{~h}^{-1}$. As an arbitrary target, we aimed to ensure that the quantity of particulates in the chamber should not fall (as a result of copepod feeding) by more than $10 \%$ from the ambient concentration. Thus a throughflow not less than $3 \mathrm{~cm}^{3} \mathrm{~h}^{-1}$ was required. Experiments were performed to determine the rate at which particulates pass through the chambers, based on the following considerations.

Let the chamber volume be $V \mathrm{~cm}^{3}$ with seawater flowing through at a rate of $U \mathrm{~cm}^{3} \mathrm{~s}^{-1}$. The water entering the chamber has a particulate concentration of $S_{1} \mathrm{~cm}^{-3}$, and at time $t$ the concentration of particulates in the chamber is $S \mathrm{~cm}^{-3}$. It is assumed that the contents of the chamber are well-mixed, and $S_{1}$ is independent of time.

At time $t$, the number of particles entering the chamber per second is $U \times S_{1}$. At the same time, the volume of water leaving the chamber per second $=U \mathrm{~cm}^{3}$.

Since the contents of the chamber are well-mixed, the water contains a particulate concentration $\mathrm{Scm}^{-3}$, so that at time $t$ the number of particles leaving the chamber per second $=U \times S$.

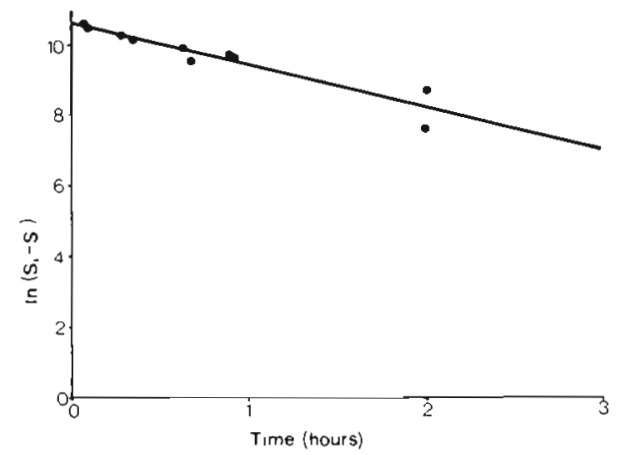

Fig. 2. Parameter determination for water flow rate through incubation chambers
Thus the rate of change of particle concentration at time $t$

$$
\frac{d S}{d t}=\frac{U\left(S_{1}-S\right)}{V}
$$

If $S=S_{0}$ at $t=0$, then $S=S_{1}-\left(S_{1}-S_{0}\right) \exp (-U / V)$

Equation 2 gives $S$ at any time $t$.

The parameters in Equation 2 were determined as follows. Ten incubation chambers of similar known volume were filled with particulate-free seawater. They were placed in trays through which seawater of known particle concentration $\left(S_{1}\right)$ was flowing at 31 $\mathrm{min}^{-1}$. Pairs of chambers were removed from the tray over a period of $2 \mathrm{~h}$, and their particulate concentration determined by Coulter Counter. From Equation 2, a plot of $\ln \left(S_{1}-S\right)$ against $t$ (Fig. 2) gave a gradient value (equivalent to $U / V$ ) of -1.185 , from which the mean velocity of particles through the chamber was calculated to be $140 \mathrm{~cm}^{3} \mathrm{~h}^{-1}$. This is some 400 times faster than the maximum filtering rate of Eurytemora affinis, according to Allan et al. (1977), and shows that the water flow rate is more than adequate to simulate 'real' conditions.

(2) Post-incubation size: To determine whether the chambers affected the growth of copepods in an unforeseen way, a comparison was made on the January cruise between the cephalothorax lengths of Eurytemora affinis that had moulted in the chamber during a 4-d period of incubation (captive individuals) and those of the same developmental stage collected at the same time as the incubated individuals and killed at the start of the incubation (wild individuals). Heinle and Flemer (1975) have shown that E. affinis reared in the laboratory are smaller than wild individuals of the same stage. The $t$-test for data with variances not assumed to be equal (Parker, 1973) was used to test the differences of the mean size of captive and wild copepods (Table 1). No significant differences were found between the cephalothorax lengths for any of the pre-adult copepodite stages of the two populations.

Table 1. Eurytemora affinis. $t$-test to check the significance between the sizes of copepods after moulting in the incubation chamber (captive) with the wild population

\begin{tabular}{|c|c|c|c|c|c|c|c|}
\hline \multirow{3}{*}{$\begin{array}{l}\text { Development } \\
\text { stage }\end{array}$} & \multicolumn{7}{|c|}{ Cephalothorax lengths of copepods (mm) } \\
\hline & \multicolumn{3}{|c|}{$\begin{array}{l}\text { Captive } \\
\text { mean }\end{array}$} & \multicolumn{2}{|c|}{ Wild } & \multirow[t]{2}{*}{ Ivalue } & \multirow[t]{2}{*}{$\mathrm{P}$} \\
\hline & mean & s. d. & range $;$ number & mean s. d. & range; number & & \\
\hline $\mathrm{CI}$ & $0.26 \pm$ & 0.02 & $(0.25-0.29 ; n=3)$ & $0.28 \pm 0.02$ & $(0.25-0.29 ; n=3)$ & 0.74 & $0.6>P>0.5$ \\
\hline CII & $0.35 \pm$ & 0.05 & $(0.29-0.40 ; n=5)$ & $0.36 \pm 0.03$ & $(0.33-0.40 ; n=12)$ & 0.05 & $P>0.9$ \\
\hline CIII & $0.43 \pm$ & 0.04 & $(0.34-0.50 ; n=16)$ & $0.43 \pm 0.02$ & $(0.40-0.43 ; \mathrm{n}=9)$ & 0.32 & $0.8>P>0.7$ \\
\hline CIV & $0.51 \pm$ & 0.03 & $(0.48-0.56 ; n=6)$ & $0.50 \pm 0.01$ & $(0.48-0.52 ; n=7)$ & 0.89 & $0.4>P>0.3$ \\
\hline CV & $0.57 \pm$ & 0.01 & $(0.56-0.58 ; n=3)$ & $0.56 \pm 0.01$ & $(0.54-0.58 ; n=5)$ & 0.76 & $0.5>P>0.4$ \\
\hline
\end{tabular}




\section{Shipboard Production Determination}

A series of cruises on board RRS 'John Murray' was carried out in May, August and October 1977 and January 1978, representing each of the 4 seasons. Due to malfunctioning of the pumped water supply, no development experiments were carried out on the August cruise.

\section{Abundance}

The abundance of Eurytemora affinis was determined by carrying out double-oblique tows through the water column to within $5 \mathrm{~m}$ of the bottom, with a Lowestoft 20" $(50.8 \mathrm{~cm})$ plankton sampler (Beverton and Tungate, 1967) towed at 6 knots. The frame was fitted with a modified conical nose-cone with a mouth reduced to $8^{\prime \prime}(20.3 \mathrm{~cm})$, and a net of $280 \mu \mathrm{m}$ mesh. On the January 1978 cruise, an auxilliary 'pup' sampler with a $56 \mu \mathrm{m}$ mesh net was used in conjunction with the Lowestoft sampler to provide data on the abundance of the smaller stages. On each cruise, a series of tows (6 in January, 16 in May and 8 in October/ November) were made along a north-south transect through Station A (Fig. 3) over a tidal cycle. On the May and October/November cruise, sets of tows were carried out before and after the development experiments.

In the laboratory, a subsample of the material obtained from each tow was analysed to determine the abundance of each developmental stage. The sampler flowmeter readings were corrected for mesh selectivity according to the data of Adams (1976) and Saville (1958) to give estimates of absolute abundance.

\section{Development Experiments}

On each of the cruises, experiments were carried out for between 3-5 d while the ship remained at anchor on Station A (Fig. 3). Observations were made daily or twice daily to check the development of copepods retained singly in incubation chambers $(38,21$ and 12 copepods were held on the January, May and October/ November cruises respectively). Throughout the incubation period, sub-surface salinity and temperature were measured continuously using a Plessey thermosalinograph model 6600T. Water samples were filtered through GF/C glass-fibre filters, stored deep frozen and subsequently extracted with $95 \%$ acetone for photosynthetic pigment analysis as outlined by Strickland and Parsons (1968). Vertical profiles of temperature, salinity and chlorophyll a showed that the water column was well mixed.

\section{Length-Weight Relationship}

In January, Eurytemora affinis were collected with a hand tow net fitted with a polythene beaker for lengthweight determination. Live specimens were carefully washed to remove particulate material and were then collected on glass-fibre pads using vacuum filtration. These were briefly rinsed with distilled water and held frozen. In the laboratory, the cephalothorax lengths of between 10 and 40 specimens of each stage were measured using an ocular micrometer. Care was taken to ensure that limbs did not stick to the planchet surface. The organisms were dried at $60^{\circ} \mathrm{C}$ and each copepod weighed using a Cahn Electrobalance.

The length (L) to weight (W) relationship for Eury-

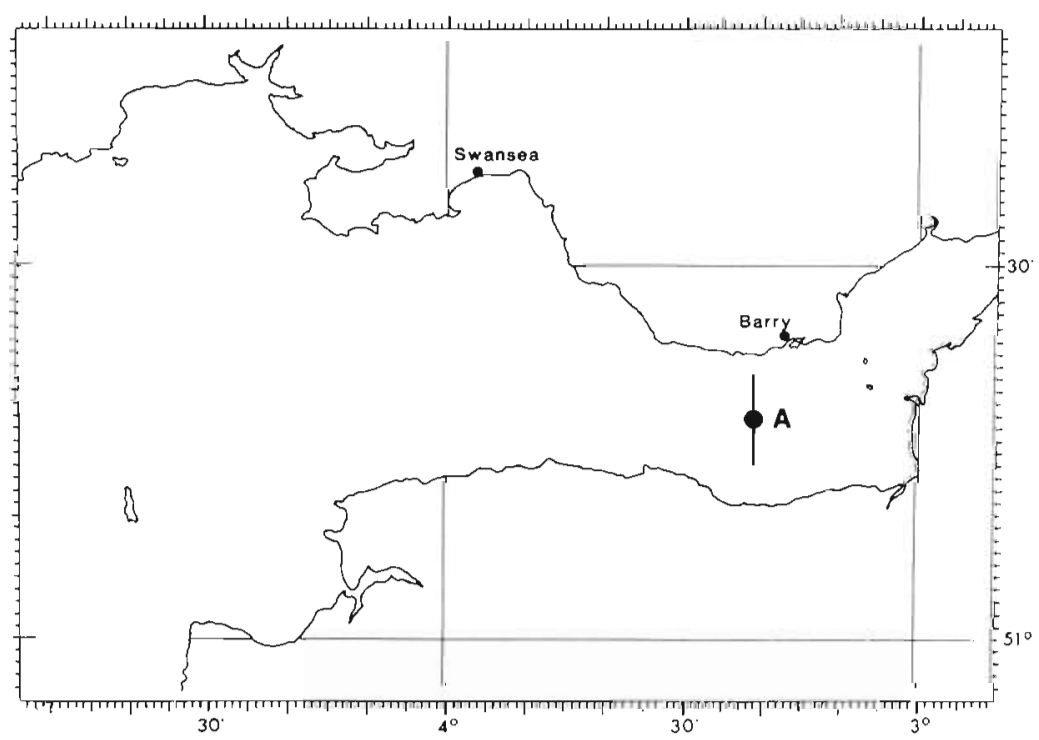

Fig. 3. Chart of Bristol Channel showing plankton tow transect (solid line) and anchor station (A) where incubations were carried out 
Table 2. Ambient environmental conditions during development studies

\begin{tabular}{|c|c|c|c|c|c|c|c|c|}
\hline \multirow[t]{2}{*}{ Month } & \multicolumn{2}{|c|}{ Temperature ${ }^{\circ} \mathrm{C}$} & \multicolumn{2}{|c|}{ Salinity \% } & \multicolumn{2}{|c|}{ Chlorophyll a $\mu \mathrm{g} \mathrm{l}^{-1}$} & \multicolumn{2}{|c|}{ Phaeopigment $\mu \mathrm{g}^{-1}$} \\
\hline & mean & range & mean & range & mean & range & mean & range \\
\hline May & 9.9 & $9.7-10.5$ & 29.1 & $26.5-31.5$ & 1.4 & $0.5-5.8$ & 1.6 & $0.4-8.0$ \\
\hline Oct. & 14.4 & $14.2-14.9$ & 30.2 & $28.4-31.8$ & 1.2 & $0.3-4.8$ & 1.8 & $0.5-5.9$ \\
\hline Jan. & 6.5 & $5.8-7.2$ & 28.5 & $25.4-31.1$ & 2.2 & $0.9-3.8$ & 3.3 & $2.3-4.2$ \\
\hline
\end{tabular}

temora affinis was described by: $\log \mathrm{W}=\mathrm{a}+\mathrm{bL}$. The equation was solved by the method of least squares. Average dry weights of individual stages were calculated from this equation using the mean length for each stage found for each cruise.

\section{Production Estimation}

The daily production of Eurytemora affinis was calculated by a method similar to that used by Mann (1969) based on the following equation

$$
P_{i \rightarrow i+1}=N_{i}\left(W_{i+1}-W_{l}\right) P M D_{1}
$$

where $P_{i \rightarrow i+1}$ equals the daily production in dry weight of Eurytemora affinis developing from Stage $i$ to Stage $i+1_{i} N_{i}$ and $W_{i}=$ abundance and dry weight respectively of individuals of Stage $i, P M D_{i}=$ proportion of the $i^{\text {th }}$ developmental stage moulting daily. $N_{1}$ and $P M D_{i}$ were determined on each cruise, and $W_{1}$ estimated using the length to weight relationship in conjunction with length measurements made of copepods obtained on each cruise.

\section{RESULTS}

\section{Ambient Conditions}

Average values and their ranges for environmental variables during the experimental period of each cruise are shown in Table 2. Although temperature changed seasonally, there was little change in either chlorophyll a or salinity between cruises.

\section{Abundance of Eurytemora affinis}

The mean abundance of Eurytemora affinis varied seasonally (Table 3), ranging from $0.24 \mathrm{~m}^{-3}$ in November to $4.83 \mathrm{~m}^{-3}$ in May. There was considerable variation in abundance between tows, indicating that the copepod is not distributed evenly in the estuary. In January, the population density had risen to $1.41 \mathrm{~m}^{-3}$. It is pertinent that naupliar stages were found in January indicating that the population was reproducing.
Table 3. Eurytemora affinis. Population abundance in the eastern Bristol Channel

\begin{tabular}{|rcc|}
\hline \multicolumn{1}{|c|}{ Date } & \multicolumn{2}{c|}{$\begin{array}{c}\text { Abundance }\left(\text { No. } \mathrm{m}^{-3}\right) \\
\text { range }\end{array}$} \\
\hline $3 / 5 / 77$ & $2.62 \pm 1.04$ & $0.54-7.40$ \\
$14 / 5 / 77$ & $4.83 \pm 1.62$ & $0.75-13.48$ \\
$25 / 10 / 77$ & $0.81 \pm 0.37$ & $0.20-2.27$ \\
$2 / 11 / 77$ & $0.24 \pm 0.02$ & $0.19-0.27$ \\
$24 / 1 / 78$ & $1.42 \pm 0.23$ & $0.91-2.26$ \\
\hline
\end{tabular}

This contrasts with oceanic species that typically overwinter at late copepodite stages, deferring reproduction until spring.

\section{Length-Weight Relationship}

Cephalothorax length showed a regular increase as the copepod developed (Fig. 4) and the variability of size generally increased with age. There were no significant differences between the sizes found on different cruises.

The length-weight relationship (Fig. 5) is described by

$\log _{10} W=2.088( \pm 0.119) L-0.859( \pm 0.083)$

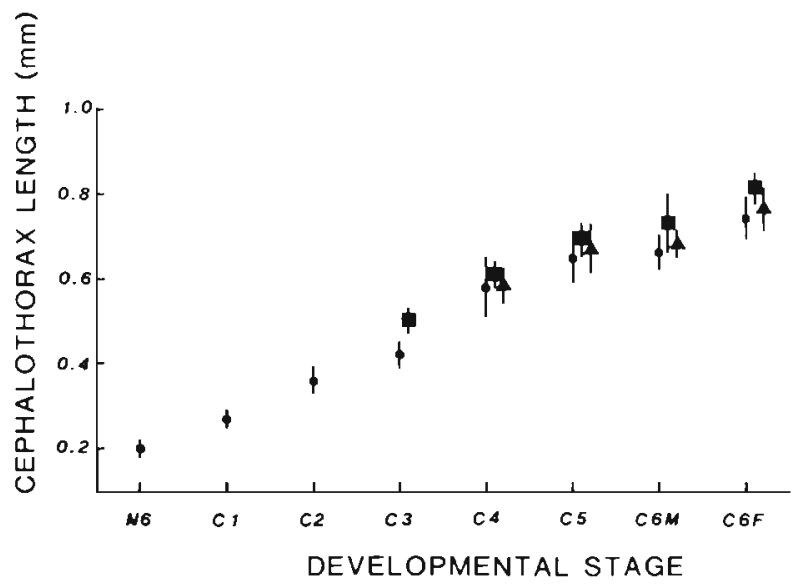

Fig. 4. Eurytemora affinis. Size of different developmental stages during January $(\bullet)$, May $(\boldsymbol{\square})$ and October $(\boldsymbol{\Delta})$. Vertical bars: standard deviations 


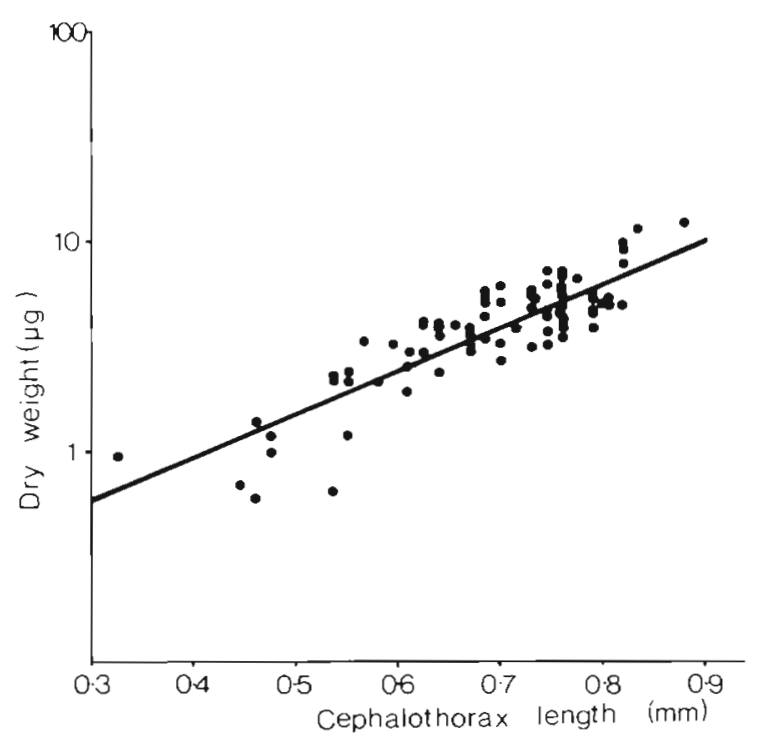

Fig. 5. Eurytemora affinis. Length to weight relationship of different developmental stages

where $W=$ dry weight in $\mu$ g; $L=$ cephalothorax length in $\mathrm{mm}$; figures in parentheses = standard deviations for parameter values. With 86 data points, the correlation coefficient was 0.885. Although copepod length/weight relationships are commonly expressed in $\log / \log$ form, in this case the $\log /$ linear equation gave a statistically better fit, as was found for adult

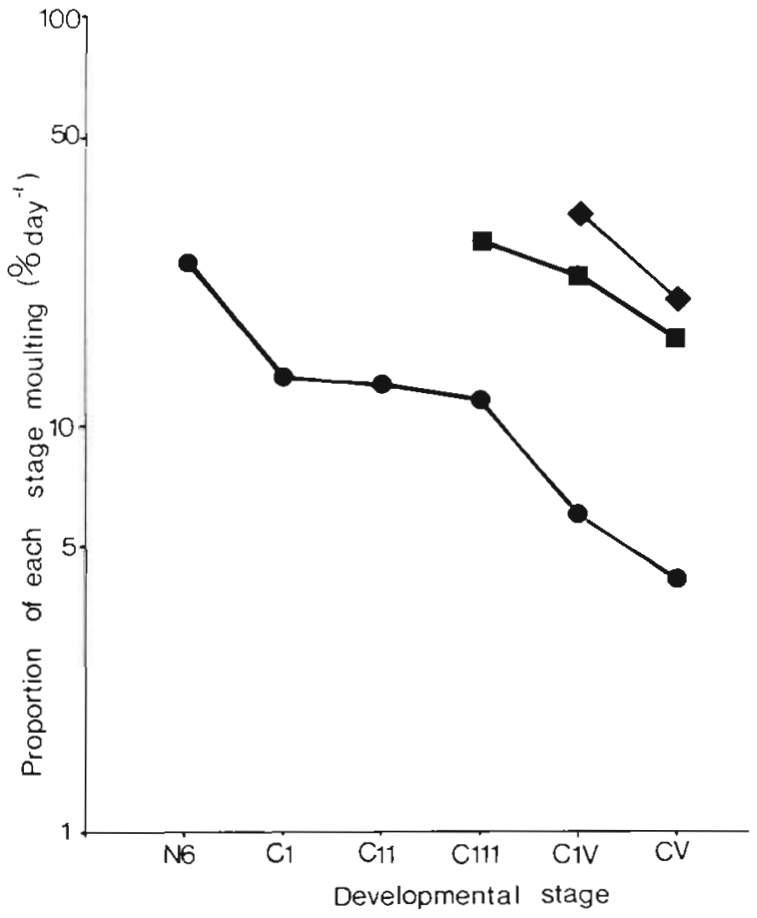

Fig. 6. Eurytemora affinis. Variation in the proportion of the population moulting daily during January (circles), May (squares), and October (diamonds)

female Eurytemora affinis (Heinle and Flemer, 1975) and for Acartia tonsa (Heinle, 1966).

Table 4. Eurytemora affinis. Standing stocks and daily production for different development stages in the Bristol Channel

\begin{tabular}{|c|c|c|c|c|c|c|c|}
\hline Date & $\begin{array}{l}\text { Development } \\
\text { stage }\end{array}$ & $\begin{array}{l}\text { Abundance } \\
\text { (no. } \mathrm{m}^{-3} \text { ) }\end{array}$ & $\begin{array}{l}\text { Dry weight } \\
(\mu \mathrm{g})\end{array}$ & $\begin{array}{l}\text { Standing crop } \\
\left(\mu g \mathrm{~m}^{-3}\right)\end{array}$ & $\begin{array}{l}\text { Weight increase } \\
\qquad(\mu \mathrm{g})\end{array}$ & $\begin{array}{l}\text { Proportion moulting } \\
\qquad\left(\% d^{-1}\right)\end{array}$ & $\begin{array}{l}\text { Production } \\
\left(\mu g \mathrm{~m}^{-3} \mathrm{~d}^{-1}\right)\end{array}$ \\
\hline $3^{\text {rd }}$ May & $\begin{array}{l}\text { C II } \\
\text { C IV } \\
\text { C V } \\
\text { C VI }\end{array}$ & $\begin{array}{l}0.36 \\
0.52 \\
0.54 \\
1.20\end{array}$ & $\begin{array}{l}1.53 \\
2.60 \\
3.82 \\
5.61\end{array}$ & $\begin{array}{l}0.55 \\
1.35 \\
2.06 \\
6.73\end{array}$ & $\begin{array}{l}1.07 \\
1.22 \\
1.79\end{array}$ & $\begin{array}{l}28.3 \\
22.9 \\
15.6\end{array}$ & $\begin{array}{l}0.109 \\
0.145 \\
0.151\end{array}$ \\
\hline $14^{\text {th }} \mathrm{May}$ & $\begin{array}{l}\text { C III } \\
\text { C IV } \\
\text { C V } \\
\text { C VI }\end{array}$ & $\begin{array}{l}0.36 \\
0.20 \\
1.60 \\
2.67\end{array}$ & $\begin{array}{l}1.53 \\
2.60 \\
3.82 \\
5.61\end{array}$ & $\begin{array}{r}0.55 \\
0.52 \\
6.11 \\
14.98\end{array}$ & $\begin{array}{l}1.07 \\
1.22 \\
1.79\end{array}$ & $\begin{array}{l}28.3 \\
22.9 \\
15.6\end{array}$ & $\begin{array}{l}0.109 \\
0.056 \\
0.447\end{array}$ \\
\hline $25^{\text {th }}$ Oct. & $\begin{array}{l}\text { C IV } \\
\text { C V } \\
\text { C VI }\end{array}$ & $\begin{array}{l}0.11 \\
0.07 \\
0.63\end{array}$ & $\begin{array}{l}2.25 \\
3.47 \\
4.85\end{array}$ & $\begin{array}{l}0.25 \\
0.24 \\
3.06\end{array}$ & $\begin{array}{l}1.22 \\
1.39\end{array}$ & $\begin{array}{l}33.3 \\
20.0\end{array}$ & $\begin{array}{l}0.045 \\
0.019\end{array}$ \\
\hline $2^{\text {nd }}$ Nov & $\begin{array}{l}\text { C IV } \\
\text { C V } \\
\text { C VI }\end{array}$ & $\begin{array}{l}0.11 \\
0.11 \\
0.02\end{array}$ & $\begin{array}{l}2.25 \\
3.47 \\
4.85\end{array}$ & $\begin{array}{l}0.25 \\
0.38 \\
0.10\end{array}$ & $\begin{array}{l}1.22 \\
1.39\end{array}$ & $\begin{array}{l}33.0 \\
20.0\end{array}$ & $\begin{array}{l}0.045 \\
0.031\end{array}$ \\
\hline $24^{\text {th }}$ Jan. & $\begin{array}{l}\text { N VI } \\
\text { C I } \\
\text { C II } \\
\text { C III } \\
\text { C IV } \\
\text { C V } \\
\text { C VI }\end{array}$ & $\begin{array}{l}0.06 \\
0.21 \\
0.11 \\
0.09 \\
0.35 \\
0.16 \\
0.44\end{array}$ & $\begin{array}{l}0.36 \\
0.51 \\
0.78 \\
1.04 \\
2.25 \\
3.15 \\
4.01\end{array}$ & $\begin{array}{l}0.02 \\
0.11 \\
0.09 \\
0.09 \\
0.79 \\
0.50 \\
1.76\end{array}$ & $\begin{array}{l}0.14 \\
0.27 \\
0.26 \\
1.21 \\
0.90 \\
0.86\end{array}$ & $\begin{array}{r}25.2 \\
12.6 \\
12.6 \\
11.7 \\
6.0 \\
4.0\end{array}$ & $\begin{array}{l}0.002 \\
0.007 \\
0.004 \\
0.013 \\
0.019 \\
0.006\end{array}$ \\
\hline
\end{tabular}




\section{Development Rates}

Development rates of Eurytemora affinis varied from stage to stage and from cruise to cruise (Fig. 6). During each experimental period, the moulting rates of the different stages were inversely related to their ages. Developmental rates also proceeded faster when water temperatures were warmer.

\section{Standing Stock}

Standing stocks of the copepod, estimated from the dry weights of each stage and their abundance, varied between $0.7 \mu \mathrm{g} \mathrm{m}^{-3}$ found on 2nd November and $22.2 \mu \mathrm{g} \mathrm{m}^{-3}$ on 14 th May (Table 4). In January, the biomass was $3.4 \mu \mathrm{g} \mathrm{m}^{-3}$.

\section{Production and $\mathrm{P} / \mathrm{B}$}

Eurytemora affinis production rates varied seasonally, the lowest rate $\left(0.051 \mu \mathrm{g} \mathrm{m}^{-3} \mathrm{~d}^{-1}\right)$ occurring in January (Table 4). In May, values of 0.405 and $0.612 \mu \mathrm{g}$ $\mathrm{m}^{-3} \mathrm{~d}^{-1}$ were estimated and rates of 0.064 and $0.076 \mu \mathrm{g}$ $\mathrm{m}^{-3} \mathrm{~d}^{-1}$ were found in October and November respectively. Production of the individual stages varied, depending on their abundance and growth rates. Despite the fact that the younger stages moulted faster than adults, the greater abundance and larger increase in weight per moult of older stages resulted in greater productivity of the CIII to CV stages in January.

The daily P/B values (Table 5) show a clear relationship with stage for each of the 3 cruises. The highest $P / B$ ratio was 0.20 for Copepodite III in May and lowest $\mathrm{P} / \mathrm{B}$ was 0.01 for Copepodite $\mathrm{V}$ in January. Population $\mathrm{P} / \mathrm{B}$, obtained by dividing the population production by standing stock varied from 0.03 in January to 0.13 in October.

Table 5. Eurytemora affinis. Daily P/B values in the eastern Bristol Channel

\begin{tabular}{|llcc|}
\hline Month & Stage & Daily P/B & Population P/B \\
\hline May & C III & 0.20 & 0.09 \\
& C IV & 0.11 & \\
Oct. & C V & 0.07 & \\
& C IV & 0.18 & 0.13 \\
Jan. & C V & 0.08 & \\
& N VI & 0.09 & 0.03 \\
& C I & 0.06 & \\
& C II & 0.05 & \\
& C III & 0.14 & \\
& C IV & 0.02 & \\
& C V & 0.01 & \\
\hline
\end{tabular}

\section{DISCUSSION}

Analysis of some of the factors likely to influence the rates of development of individuals and the population of Eurytemora affinis will be discussed below. Estimates of production of copepods in estuaries and neritic regions are uncommon. The available data for some species are summarised in Table 6 showing that $P / B$ quotients vary between species and contrasting environments. Our estimate for Eurytemora affinis (P/B of $\left.33 \mathrm{yr}^{-1}\right)$ is toward the upper end of the values found in temperate regions. The data of Heinle (1966) and Newbury and Bartholomew (1976) with $\mathrm{P} / \mathrm{B}$ values of $182 \mathrm{yr}^{-1}$ for Acartia tonsa and $285 \mathrm{yr}^{-1}$ for mixed copepod species, were derived in regions with higher summer temperatures.

A school of thought advocated by McLaren and others (McLaren and Corkett, 1981, and papers cited therein) proposes that copepods commonly develop in the field at maximal rates. This significant concept suggests that development may be determined by factors other than food which is deemed to be present in excess. Temperature is the environmental variable which is usually considered to limit development (e.g. McLaren and Corkett, 1981). This idea has the attractive corollary that estimating copepod production in nature is made easier to compute, since laboratory data on development rates made under conditions of excess food may be used. How do our rates compare with such laboratory-derived rates?

Comparison of our data with laboratory rates is not straightforward because of the different ways in which experiments were carried out and results recorded. Assuming that the development times of Eurytemora affinis recorded by Heinle and Flemer (1975) are equivalent to the reciprocal of PMD and that for our data, the relative development rates of different stages remain as found in January, comparisons are possible. Table 7 suggests that development times are faster with individuals fed on algae Isochrysis galbana, Chlamydomonas reinhardti and Chaetoceros sp. by Heinle and Flemer (1975) than was found by our in-situ technique. Assuming this is not a methodological problem, this suggests that $E$. affinis is living in a nutritionally sub-optimal environment. Moreover, the degree of sub-optimality alters seasonally, since the discrepancies in the development times are larger in winter $(90 \%$ difference) than in summer $(36 \%)$ or autumn (18\%). The discrepancies cannot be related simply to algal concentrations in-situ since chlorophyll a concentrations were similar in winter and summer (Table 2). In this environment, the seston comprises principally detrital silt and other tidally resuspended material with a high inorganic content. Although E. affinis ingests this material (Fig. 1 and pers. obs.), it is 
Table 6. P/B quotients of some copepods in neritic regions

\begin{tabular}{|c|c|c|c|c|c|}
\hline Species & Region & $\begin{array}{c}\text { Temperature } \\
\left({ }^{\circ} \mathrm{C}\right)\end{array}$ & $\begin{array}{l}\text { Daily } P / B \\
\left(d^{-1}\right)\end{array}$ & $\begin{array}{c}\text { Annual } P / B \\
\left(y^{-1}\right)\end{array}$ & Source \\
\hline Pseudocalanus elongatus & Gdansk Bay & $3-7$ & $.01-.05$ & 12 & Ciszewski and Witek (1977) \\
\hline Copepod ssp. ${ }^{a}$ & Kungsbacka Fjord & $7-14$ & $.02-.06$ & 15 & Olsson and Olundh (1974) \\
\hline Acartia clausi & Black Sea & & .04 & 16 & Zaika $\{1968\}$ \\
\hline Oithona similis & Nearshore Black Sea & & .04 & 16 & Zaika (1968) \\
\hline Acartia bifilosa & Gdansk Bay & $7-18$ & $.03-.12$ & 17 & Ciszewski and Witek (1977) \\
\hline Paracalanus parvus & Nearshore Black Sea & & .07 & 25 & Greze et al. (1968) \\
\hline Oithona minuta & Nearshore Black Sea & & .08 & 31 & Greze et al. (1968) \\
\hline Acartia clausi & Nearshore Black Sea & & .09 & 32 & Greze et al. (1968) \\
\hline Eurytemora affinis & East. Bristol Channel & $6-14$ & $.03-.13$ & 33 & This study \\
\hline Acartia clausi & $\begin{array}{l}\text { Coastal lagoon } \\
\text { Washington }\end{array}$ & $8-20$ & $.12-.23$ & $57^{c}$ & Landry $(1978)$ \\
\hline Pseudocalanus elongatus & Nearshore Black Sea & & .16 & 58 & Greze et al. (1968) \\
\hline Eurytemora herdmani & Halifax & $8-18$ & ca. $.16-.17^{c}$ & - & McLaren and Corkett (1981) \\
\hline Acartia tonsa & $\begin{array}{l}\text { Patuxent River } \\
\text { Chesapeake Bay }\end{array}$ & $0-32$ & .50 & $182^{c}$ & Heinle (1966) \\
\hline Copepod $\mathrm{spp}^{\mathrm{b}}$ & Hawaii lagoon & $27-29$ & .78 & $285^{c}$ & Newbury and Bartholomew (1976) \\
\hline
\end{tabular}

Table 7. Eurytemora affinis. Comparison of development times of the copepod under simulated in-situ conditions and fed on algae (After Heinle and Flemer, 1975)

\begin{tabular}{|c|c|c|}
\hline Temperature & \multicolumn{2}{|c|}{ Development time from CI to CVI (d) } \\
\hline & This study ${ }^{a}$ & Algal fed ${ }^{c}$ \\
\hline $5.5-6.5$ & 66 & 35 \\
\hline $9.9-10$ & $19^{b}$ & 14 \\
\hline $14.2-15$ & $13^{b}$ & 11 \\
\hline \multicolumn{3}{|c|}{$\begin{array}{l}\text { a: Obtained by summing reciprocals of PMD values for } \\
\text { each size } \\
\text { b: Assuming same proportion of duration between stages } \\
\text { as January } \\
\text { c: From Heinle and Flemer (1975) }\end{array}$} \\
\hline
\end{tabular}

likely to be assimilated less readily than algae and thus may 'dilute-out' the algal food. Although seston data were not recorded during development experiments, it is known from other work in the region that particulate levels during winter can be 3 to 6 times the values found in summer (IMER, unpubI.). In this case, the phytoplankton-to-seston levels would be lower in winter than summer. We thus put forward the hypothesis that development of E. affinis in this environment may be related to a 'phytoplankton-to-seston' ratio which may act as an index of food availability.

A further factor that may influence the development performance of Eurytemora affinis is salinity. It is known that the centre of abundance of this species is typically found at salinities less than 15-20\% S (e.g. Cronin et al., 1962; Jeffries, 1962). In the Severn Estuary the abundance of $E$. affinis, some $30 \mathrm{~km}$ upstream has been found, on occasion, to be 2 or 3 orders of magnitude higher than was found in this study (Burkill, unpubl.). Thus, the copepods found in the Bristol Channel form a component of the population that may be 'washed-out' by the net water movement down the estuary. Outside its apparent salinity optimum, the species' capacity to grow may be impaired. However, since salinity altered little from cruise to cruise (Table 2), the seasonal variation in the discrepancies in development times, discussed earlier, cannot be explained simply by salinity effects. Moreover, we have frequently observed adults mating and females carrying spermatophores and egg-sacs in this region and this, together with the results of this research, suggest the population is capable of reproducing at $30 \% \mathrm{~S}$, which is much higher than the salinity at its centre of abundance. Our findings tend to confirm Katona (1970) who recorded that E. affinis reproduced at $33 \% \mathrm{~S}$ with generation times not significantly different from those found at $5 \%$ or $20 \% \mathrm{~S}$. In fact, Bradley (1975) in a study of the physiological tolerance of $E$. affinis to temperature and salinity, concluded that there was no cause-effect relationship between salinity and the distribution of this copepod, and suggested that other factors had to be considered to explain the observed distribution. Among the factors that might affect the distribution and population development of E. affinis are passive transport by water movement and predation.

Does hydrodynamic flushing have a significant effect on the copepod population? Analysis of the effects of this process in detail is beyond the scope of this paper, although it is possible to compare, in a simple manner, the flushing rate of the estuary with the copepod's growth rate using chemostat theory. This 
assumes the copepod behaves as a conservative dissolved constituent of seawater and the population is under steady state conditions. If $B$ is the copepod biomass, $G$ its growth rate and $F$ the estuary's flushing rate (the proportion of the estuarine volume that is exchanged per unit time) then, under steady state,

the rate of change of biomass $=B e^{G}-F B$

For the copepod to maintain itself in the estuary, its growth rate must equal or exceed the rate at which it is flushed out, i.e. $G \log _{e}(1+F)$.

Uncles and Radford (1980) have determined the residence times (equal to $1 / F$ ) of the estuary landward of the experimental site to vary between $60 \mathrm{~d}$ and $150 \mathrm{~d}$. These data give values for the right-hand side of the above equation of $0.007 \mathrm{~d}^{-1}$ and $0.017 \mathrm{~d}^{-1}$. In contrast, $G$ (equal to P/B quotient) varies between $0.03 \mathrm{~d}^{-1}$ and $0.13 \mathrm{~d}^{-1}$ suggesting the copepod is well able to maintain itself in this part of the estuary. Upstream where the flushing will be very much higher, it is likely that the copepod will be more greatly affected by this process.

Is predation a factor influencing the Eurytemora affinis population? Several carnivorous species were found in the plankton hauls carried out to estimate copepod abundance. There was an inverse relationship between the abundance of $E$. affinis and carnivore abundance (Fig. 7), suggesting that predation influences the abundance of this copepod. In January, the commonest planktonic group capable of taking $E$. affinis are mysids (Gastrosaccus spinifer, Schistomysis spiritus and Schistomysis ornata). Copepod remains have been recorded in the stomachs of $S$. ornata and $S$.

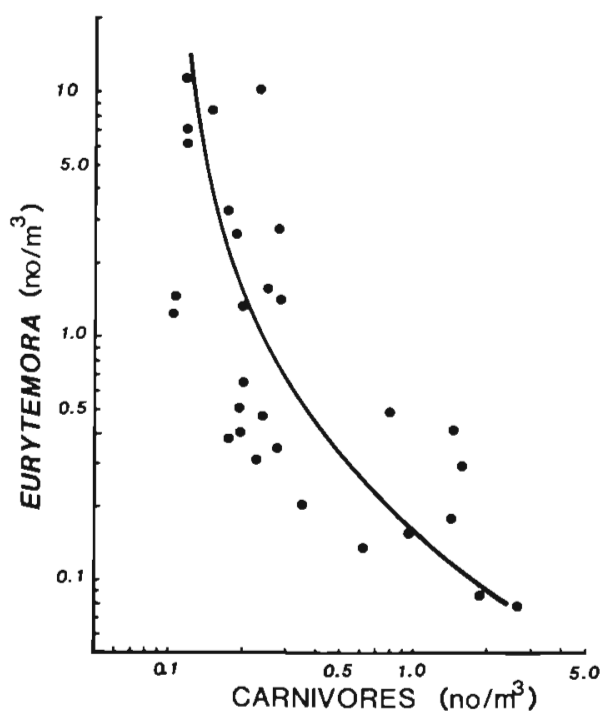

Fig. 7. Eurytemora affinis. Abundance as a function of carnivore abundance for separate hauls made in January, May and October. Line is fitted by eye spiritus (Mauchline, 1967, 1970), and evidence of carnivory by $G$. spinifer has been reported by Blegvad (1915). In Chesapeake Bay, the mysid (Neomysis integer) was found to consume E. affinis and mortality due to predation was the principal cause of the spring decrease in population levels (Heinle and Flemer, 1975). In May, decapods such as Crangon crangon and Pasiphaea sivado formed the largest component capable of consuming copepods. In the Severn Estuary, the former species is known to take animal material (Lloyd and Yonge, 1947). Although the diet of $P$. sivado is unknown, the related species, $P$. multidentata consumed copepods as a substantial part of their diet (Apollonia, 1969). Chaetognaths (Sagitta spp.) dominated the carnivorous component of the plankton in October. In addition to the invertebrate predators, it is known that fish are predators of E. affinis: Hardy (1924) found that this species was the most important item in the food of young herring (Clupea harengus) in the Thames Estuary. In the Solway Firth, E. affinis was found in considerable numbers in the stomachs of herring, cod, dab and plaice (Scott, 1902). Although the numbers of fish in our plankton samples were low, over 40 species of fish have been found in the region and the area has been considered important, both as a route for migratory species and as a nursery area for postlarval and juvenile stages of a number of marine species (Hardisty and Huggins, 1975).

It seems therefore that in a region with a salinity higher than that at the centre of abundance, the population density and production of Eurytemora affinis were low (range 0.2 to $4.8 \mathrm{~m}^{-3}$ and 0.05 to $0.61 \mu \mathrm{g} \mathrm{m}^{-3}$ $\mathrm{d}^{-1}$ ), but the species was capable of growing with a P/B quotient of $33 \mathrm{yr}^{-1}$, which is higher than many recorded values for copepods. However, the $\mathrm{P} / \mathrm{B}$ quotient for $E$. affinis is expected to be higher in nutritionally optimal environments since faster development rates were recorded by Heinle and Flemer (1975) than found here. Of the environmental factors considered, apart from nutrition, it is suggested that predation influences the levels of population and that salinity and flushing in this region are not so important. A more definitive analysis of the separate effects of the different environmental factors on $E$. affinis would require further work under controlled conditions. Development rates for individuals feeding on natural particulates were lower $(10 \%-82 \%)$ than published values for copepods fed artificially on algae suggesting that extrapolation of laboratory results to estimate growth rates in the natural environment should be carried out with care.

Acknowledgements. We thank the crews and fellow scientists working on board RRS 'John Murray' for their help and cooperation during this work. We are grateful to Mrs. G. Bailey for assistance in data work-up, to Mr. A. H. Taylor for advice on hydrodynamics and Drs B. L. Bayne, H. H. Bottrell, D. C. 
Brownlee, R. P. Harris, R. C. Newell, R. Williams and 2 anonymous reviewers for their constructive comments on the manuscript.

This work forms part of the estuarine and near shore programme of the Institute for Marine Environmental Research, a component of the Natural Environment Research Council. The programme was supported, in part, by the Department of the Environment contract no $480 / 48$.

\section{LITERATURE CITED}

Adams, J. (1976). The Bridger version of the Gulf III High Speed plankton sampler Scott. Fish. Res. Rep. 3: 1-42

Allan, J. D., Richman, S., Heinle, D. R., Huff, R. (1977). Grazing in juvenile stages of some estuarine calanoid copepods. Mar. Biol. 43: 317-331

Apollonio, S. (1969). Breeding and fecundity of the glass shrimp, Pasiphaea multidentata (Decapoda, Caridea), in the Gulf of Maine. J. Fish. Res. Bd Can. 26: 1969-1983

Beverton, R. J. H., Tungate, D. S. (1967). A multi-purpose plankton sampler. J. Cons. perm. int. Explor. Mer 31: 145-157

Blegvad, H. (1915). Food and conditions of nourishment among the communities of invertebrate animals found on or in the sea bottom in Danish waters. Rep. Dan. biol. Stn 22: 41-78

Bradley, B. P. (1975). The anomalous influence of salinity on temperature tolerance of summer and winter populations of the copepod Eurytemora affinis. Biol. Bull. mar. biol. Lab. Woods Hole 148: 26-34

Butler, E. I., Knox, S., Liddicoat, M. I. (1979). The relationship between inorganic and organic nutrients in sea water. J. mar. biol. Ass. U.K. 59: 239-250

Ciszewski, P., Witek, Z. (1977). Production of older stages of copepods, Acartia bifilosa Giesb. and Pseudocalanus elongatus Boeck in Gdansk Bay. Pol. Arch. Hydrobiol. 24: $449-459$

Collins, N. R., Williams, R. (unpubl.). Zooplankton of the Bristol Channel and Severn Estuary. The distribution of four copepods in relation to salinity.

Cronin, L. E., Daiber, J. C., Hulbert, E. M. (1962). Quantitative seasonal aspects of zooplankton in the Delaware River Estuary. Chesapeake Sci. 3: 63-93

Greze, V. N., Baldina, E. P., Bileva, O. K. (1968). Production of planktonic copepods in the neritic zone of the Black Sea. Oceanology 8: 839-843

Gulland, J. A. (ed.) (1971). The fish resources of the ocean, Fishing News (Books) Ltd., West Byfleet, Surrey

Hardisty, M. W., Huggins, R. J. (1975). A survey of the fish populations of the middle Severn Estuary based on power station sampling. Int. J. environ Stud. 7: 227-242

Hardy, A. C. (1924). The herring in relation to its animate environment. Part 1 . The food and feeding habits of the herring with special reference to the east coast of England. Fishery Invest., Lond. (Ser 2) 7: 1-53

Harris, R. P., Paffenhöfer, G.-A. (1976a). The effect of food concentration on cumulative ingestion and growth efficiency of two small marine planktonic copepods. J. mar. biol. Ass. U.K. 56: 875-888

Harris, R. P., Paffenhöfer, G.-A. (1976b). Feeding, growth and reproduction of the marine planktonic copepod Temora longicornis Müller. J. mar. biol. Ass. U.K. 56: 675-690

Harvey, H. W. (1955). The chemistry and fertility of sea waters, Cambridge University Press, Cambridge

Heinle, D R. (1966). Production of a calanoid copepod, Acartia tonsa, in the Patuxent River Estuary. Chesapeake Sci 7: $59-74$
Heinle, D. R., Flemer, D. A. (1975). Carbon requirements of a population of the estuarine copepod Eurytemora affinis. Mar Biol. 31: 235-247

Jeffries, H. P. (1962). Salinity - space distribution of the estuarine copepod genus Eurytemora. Int. Revue ges. Hydrobiol. Hydrogr. 47: 291-300

Joint, I. R., Pomroy, A. J. (in press). Aspects of microbial heterotrophic production in a highly turbid estuary. J. exp. mar. Biol. Ecol.

Katona, S. K. (1970). Growth characteristics of the copepods Eurytemora affinis and E. herdmani in laboratory cultures. Helgoländer wiss. Meeresunters. 20: 373-384

Katona, S. K. (1971). The developmental stages of Eurytemora affinis (Poppe, 1880) (Copepoda, Calanoida), raised in laboratory cultures, including a comparison with the larvae of Eurytemora americana Williams, 1906, and Eurytemora hardmani Thompson and Scott, 1897. Crustaceana 21: $5-20$

Koblenz-Mishke, O. J., Volkovinsky, V V., Kabavona, J. G. $(1970)$. Plankton primary production of the world ocean. In: Wooster, W. S. (ed.) Scientific exploration of the South Pacific. National Academy of Sciences, Washington, pp. 183-193

Landry, M. R. (1978). Population dynamics and production of a planktonic marine copepod, Acartia clausii, in a small temperate lagoon on San Juan Island, Washington. Int. Revue ges. Hydrobiol. 63: 685-727

Lloyd, A. J., Yonge, C. M. (1947). The biology of Crangon vulgaris in the Bristol Channel and Severn Estuary. J. mar. biol. Ass. U.K. 26: 626-661

Mann, K. H. (1969). The dynamics of aquatic systems. In: Cragg, J. B. (ed.) Advances in ecological research. Academic Press, London, pp. 1-8

Mauchline, J. (1967). The biology of Schistomysis spiritus (Crustacea, Mysidacea). J. mar. biol, Ass. U.K. 47: 383-396

Mauchline, J. (1970). The biology of Schistomysis ornata (Crustacea, Mysidacea). J. mar. biol. Ass. U.K. 50: 169-175

McLaren, I. A., Corkett, C. J. (1981). Temperature dependent growth and production by a marine copepod. Can. J. Fish. Aquat. Sci. 38: 77-83

Newbury, T. K., Bartholomew, E. F. (1976). Secondary production of microcopepods in the southern, eutrophic basin of Kameohe Bay, Oahu, Hawaiian Islands. Pacif. Sci. 30: 373-384

Olsson, I., Olundh, E. (1974). On plankton production in Kungsbacka Fjord, an estuary on the Swedish west coast. Mar. Biol. 24: 17-28

Paffenhöfer, G.-A. (1970). Cultivation of Calanus helgolandicus under controlled conditions. Helgoländer wiss. Meeresunters. 20: 346-359

Paffenhöfer, G.-A., Harris, R. P. (1976). Feeding, growth and reproduction of the marine planktonic copepod Pseudocalanus elongatus Boeck. J. mar. biol. Ass. U.K. 56: $327-344$

Parker, R. E. (1973). Introductory statistics for biology, Edward Arnold, London

Richman, S., Heinle, D. R., Huff, R. (1977). Grazing by adult estuarine calanoid copepods of the Chesapeake Bay. Mar Biol. 42: 69-84

Saville, A. (1958). Mesh selection of plankton nets. J. Cons perm. int. Explor. Mer 23: 192-201

Scott, $T$ (1902). Observations on the food of fishes. Rep. Fish. Bd Scotl. 1902: 486-538

Sheldon, R. W., Parsons, T R. (1967). A practical manual on the use of the Coulter Counter in marine research, Coulter Electronics Sales Co., Toronto

Steeman-Nielsen, E. (1952). The use of radioactive carbon 
$\left({ }^{14} \mathrm{C}\right)$ for measuring organic production in the sea. J. Cons. perm. int. Explor. Mer 18: 117-140

Strickland, J. D. H., Parsons, T. R. (1968). A practical handbook of seawater analysis. Bull. Fish. Res. Bd Can. 167: 1-311

Tranter, D. J. (1976). Herbivore production. In: Cushing D. H., Walsh, J. J. (eds.) The ecology of the seas. Blackwell Scientific Publications, Oxford, pp. 186-224

Uncles, R. J., Radford, P. J. (1980). Seasonal and spring-neap tidal dependence of axial dispersion coefficients in the
Severn - a wide, vertically mixed estuary. J. Fluid Mech. 98: 703-726

Warwick, R. M., Price, R. (1975). Macrofauna production in an estuarine mud-flat. J. mar biol. Ass. U.K. 55: 1-18

Wotton, R. S. (1977). The size of particles ingested by moorland stream blackfly larvae (Simuliidae). Oikos 29: 332-335

Zaika, V E. (1968). Age-structure dependence of the specific production in zooplankton populations. Mar Biol. 1: 311-315

This paper was submitted to the editor: it was accepted for printing on September 7,1981 